\title{
Reaction of some Nicotiana Species to the Pepper- and Common Tobacco-Mosaic Viruses
}

\author{
J. Adsuar and L. López Matos ${ }^{1}$ \\ INTRODUCTION
}

As a result of a survey recently conducted with the purpose of determining the viruses attacking the filler-type tobacco grown in Puerto Rico it developed that the prevalent viruses on this crop were: Common tobaccomosaic virus, pepper-mosaic virus, and leaf curl virus, in that respective order of importance.

The pepper-mosaic virus was found originally in pepper by Roque and Adsuar, (1) ${ }^{2}$ and more recently was shown by Perez and Adsuar (2) to be serologically identical with the $\mathrm{Y}$ (Cornell strain) ${ }^{3}$ virus of potato. Peppermosaic virus is transmissible by mechanical means and also by the green peach aphid, Myzus persiceae. The leaf-curl virus has been under study by Bird at this Station and is indistinguishable from the virus causing leaf curl and tobacco Kroepoek, as reported from other parts of the world. Leaf curl is transmitted only by the white fly Bemisia tobaci and has been found to cause a mosaic of "tuatúa", Aderonopium gossypifolium, a weed present in the Island. However, leaf curl, as far as we have been able to observe, occurs only sporadically and does not as yet present any serious menace to tobacco.

In view of the situation disclosed by the survey it was considered of interest to explore the possibilities offered by testing different varieties and species of Nicotiana with the objective of finding sources of resistance to the viruses prevalent on tobacco in our fields.

\section{METHODS AND MATERIALS}

Seed of the different species of Nicotiana were kindly supplied by Lawrence Burke, geneticist, Tobacco Special Crops Section, U.S.D.A., Beltsville, Md. These were planted in sterilized soil and transplanted 3 to 4 weeks later into 5 -inch pots filled with sterile soil. The plants were inoculated when about 2 months old by rubbing the leaves, previously dusted with carborundum, with the inoculum. Inoculum was prepared by macerating leaves from tobacco plants infected with either pepper mosaic or common tobacco.mosaic, and extracting the juice. In order to check the presence and infectivity of the viruses used, the inoculum was tested on plants of

${ }^{1}$ Pathologist and Assistant Plant Pathologist respectively, Agricultural Experiment Station, University of Puerto Rico, Río Piedras, P. R.

${ }^{2}$ Numbers in parentheses refer to Literature Cited, p. 171.

${ }^{3}$ Kindly supplied by A. F. Ross, Cornell University, Ithaca, N. Y. 
cross-absorption tests show that the P.R.P.M. antigen removed all antibodies to the $\mathrm{Y}$ antigen from the $\mathrm{Y}$ antisera. However when P.R.P.M. antiserum 929 was absorbed with $\mathrm{Y}$ antigen it still retained some precipitating power for the P.R.P.M. antigen, reacting at a dilution of $1 / 20$ (final dilution). This indicates the presence of a minor antigen in P.R.P.M. virus, which is absent from the $\mathrm{Y}$ virus. P.R.P.M. antiserum 971 did not react in the same way as 929 , but this may be explained on the basis of its titer being fourfold lower than that of 929 . It is well known that weak and strong sera behave differently both qualitatively and quantitatively (5).

\section{SUMMARY}

Antisera were prepared against the Puerto Rican pepper-mosaic virus (P.R.P.M.) and a typical strain of potato virus $\mathrm{Y}$ by inoculating rabbits with clarified sap from tobacco plants infected separately with each virus. All the four sera thus prepared reacted with both antigens. Cross-absorption tests showed that the P.R.P.M. virus possessed a minor antigenic component not found in the $Y$ virus.

\section{RESUMEN}

Se prepararon antisueros para el virus que produce el mosaico del pimiento en Puerto Rico (P.R.P.M.) y una cepa tipo del virus $Y$ que ataca la papa, inoculando conejos con el jugo clarificado de plantas de tabaco infectadas separadamente con cada uno de estos virus. Todos los cuatro sueros, así preparados, reaccionaron con ambos antígenos. Pruebas cruzadas de absorción demostraron que el virus P.R.P.M. posee componentes antigénicos que no se encuentran en el virus $Y$.

\section{IITERATURE CITED}

1. Roque, A., and Adsuar, J., Studies on the mosaic of peppers (Capsicum frutescens) in Puerto Rico, J. Agr. Univ. P.R., 25(4) 1-11, 1941.

2. Johnson, J., Transmission of viruses from apparently healthy potatoes, Wis. Agr. Exp. Sta. Bul. 63, 1925.

3. Blodgett, F. M., A potato virus on peppers; Phytopath. 17 775-82 1936.

4. Bald, J. G., and Norris, D. O., Virus C from an old Australian variety of potato, Phytopath. 35 591-7, 1945.

5. Kleczkowski, A., Quantitative studies on serological reactions of some plant viruses and of a pea nodule bacterium, Brit. J. Exp. Path. 22 44, 1941. 
tobacco carrying the $n n$ factor for the common tobacco mosaic virus, and on Large Bell Hot pepper, already known as a differential host (1) for the pepper-mosaic virus, and in which pepper-mosaic virus causes a character-

TABLE 1.-Results of inoculating some Nicotiana species with pepper and common tobacco mosaic viruses ${ }^{1}$

\begin{tabular}{|c|c|c|c|c|c|c|}
\hline \multirow{2}{*}{ Species } & \multicolumn{2}{|c|}{ Inoculum } & \multicolumn{2}{|c|}{ Symptoms } & \multicolumn{2}{|c|}{ Source of inoculum } \\
\hline & PMV & TMV & PMV & TMV & PMV & TMV \\
\hline Nicotiana pauciflora & - & - & & & & \\
\hline$N \cdot$ glauca & $0 / 8$ & $0 / 5$ & & . & N. tobacum & N. tobacum \\
\hline N. undulata & $7 / 8$ & $4 / 4$ & VC-M-LD & NS & do. & Do. \\
\hline N. acuminata & $8 / 8$ & $?$ & N-D & & do. & Do. \\
\hline N. repanda & $8 / 8$ & $6 / 6$ & VC-M-C & NS & do. & Do. \\
\hline N. tomentosiformis & $0 / 8$ & $5 / 6$ & & VC-C-M & do. & Do. \\
\hline$N$. velutina & $5 / 12$ & $3 / 3$ & VC-M-C & VC-M-C-LD & do. & Do. \\
\hline N. clevelandii & $4 / 4$ & $3 / 3$ & $\mathrm{~N}-\mathrm{D}$ & VC-C-D & do. & Do. \\
\hline$N$. bonariensis & $2 / 3$ & $4 / 4$ & VC-C-M & VC-C-M & do. & Do. \\
\hline N. debneyi & $7 / 8$ & $3 / 3$ & VC-C-M & VC-C-M & do. & Do. \\
\hline N. corymbosa & - & - & & & & \\
\hline N. angustifolia & $1 / 3$ & $2 / 2$ & VC-C-M-N-D & NS & $N \cdot$ repanda & N. tabacum \\
\hline$N$. benthamiana & $4 / 4$ & $2 / 2$ & VC-C-IMI & VC-C & do. & Do. \\
\hline$N$. bigelovii & $8 / 8$ & $?$ & VC-C-MI & & N. tabacum & Do. \\
\hline N. otophora & $0 / 8$ & $3 / 3$ & & VC-C-M & N. repanda & Do. \\
\hline N. palmeri & $7 / 7$ & $2 / 3$ & VC-C-IM & VC-C-M-LD & do. & Do. \\
\hline$N$. paniculata & $8 / 8$ & $3 / 3$ & $\mathrm{VC}-\mathrm{C}-\mathrm{M}$ & VC-C-M-LD & N. tabacum & Do. \\
\hline N. occidentalis & $1 / 1$ & $1 / 1$ & $\mathrm{VC}-\mathrm{M}$ & VC-M & do. & Do. \\
\hline$N$. longiflora & $7 / 8$ & $3 / 3$ & VC-M-C & VC-C & do. & Do. \\
\hline N. megalosiphon & $8 / 8$ & $3 / 3$ & VC-C-MI & VC-C-M & do. & Do. \\
\hline N. maritima & $2 / 2$ & $2 / 2$ & VC-C-MI & VC-C-M-LD & do. & Do. \\
\hline$N$. gossei & $8 / 8$ & $6 / 6$ & VC-M & NS & do. & Do. \\
\hline N. goodspedii & $7 / 7$ & $3 / 3$ & VC-M & NS & do. & Do. \\
\hline N. glutinosa & $7 / 8$ & $1 / 1$ & VC-C-M & NS & do. & Do. \\
\hline
\end{tabular}

${ }^{1}$ Numerator-plant infected; denominator-plants inoculated. PMV = pepper mosaic virus; TMV = tobaceo mosaic virus; $-=$ seed did not germinate; ? = no plants available for testing; $\mathrm{VC}=$ vein clearing; $\mathrm{M}=$ mottling; $\mathrm{N}=$ necrosis; $\mathrm{NS}=$ localized necrotic spots only; $\mathrm{C}=$ chlorosis $; \mathrm{LD}=$ leaf deformation; $\mathrm{D}=$ death of plant.

istic systemic vein necrosis, defoliation, and death. All inoculated plants were kept in the greenhouse held at a temperature of $70^{\circ}$ to $98^{\circ} \mathrm{F}$. All trials were conducted between November 1954 and January 1955.

\section{RESULTS}

The results of the inoculation performed on the different Nicotiana species are presented in table 1. Some of the species refused to germinate; others did 
so poorly. This accounts for the very limited number of plants inoculated in some of the tests.

Of the 24 species tested, $N$. glauca, $N$. tomentosiformis, and $N$. otophora were found to remain symptomless when inoculated with the pepper-mosaic virus. As shown in table 1, N. glauca was the only one of the species showing resistance to both viruses.

Attempts were made to determine the presence of pepper-mosaic virus in symptomless $N$. glauca, $N$. tomentosiformis, and $N$. otophora, by extracting leaf juice and inoculating back into the Large Bell Hot pepper. $N$. glauca was found free from pepper virus in all cases. $N$. tomentosiformis juice caused mottling and chlorosis in some cases, but no systemic vein necrosis in the Large Bell Hot. Only one $N$. otophora of several plants tested produced systemic vein necrosis in the differential host.

\section{CONCLUSION}

The survey conducted during the past 2 years throughout the filler-type tobacco regions of the Island clearly indicated that the two most important and prevalent viruses are the common tobacco- and pepper-mosaic viruses. There are already in existence several mosaic-resistant tobacco varieties, but we know very little about their adaptability to our conditions. We know of no other source of resistance to the pepper mosaic except the species reported in this paper. Although the possibility still exists of finding better sources of resistance in the genus Nicotiana against the two viruses already mentioned, we consider that efforts should be made to incorporate, if possible, the resistance shown by the above-mentioned Nicotiana species into our best commercial tobacco types in order to produce resistant varieties better adapted to our conditions.

\section{RESUMEN}

Como resultado de un censo verificado con el propósito de determinar los virus predominantes en el tabaco de tripa (filler tobacco) que se cultiva en Puerto Rico, se encontró que los dos más importantes son el causante del mosaico común y el del mosaico del pimiento de Puerto Rico.

Se inocularon 24 especies de Nicotiana para determinar su resistencia a estos dos virus.

Se encontró que las especies $N$. glauca, $N$. tomentosiformis, y $N$. otophora no presentan síntomas al ser inoculadas con el virus causante del mosaico del pimiento de Puerto Rico.

La $N$. glauca es aparentemente resistente a ambos virus.

Por lo tanto se aconseja tratar de cruzar especialmente la $N$. glauca con 
nuestros mejores tabacos para incorporarle a estos la resistencia adecuada a los dos virus arriba mencionados.

\section{LITERATURE CITED}

1. Roque, A., and Adsuar, J., Studies on the mosaic of peppers (Capsicum frutescens) in Puerto Rico, J. Agr. Univ. P.R. 25 (4) 40-50, 1941.

2. Pérez Otero, E., and Adsuar, J., The antigenic relationship between the P. R. pepper-mosaic virus and potato virus $Y, J$. Agr. Univ. P. R. 39 (3) 165-7, 1955. 